\title{
Historic traceology as a complex tool for rediscovery of lost construction skills and techniques
}

\author{
J. Bláha \\ Institute of Theoretical and Applied Mechanics AS CR, Czech Republic
}

\begin{abstract}
There are various macroscopic traces recognizable and readable on the surfaces of historical structures and materials. According to their origin they can be divided into several groups including traces of the transportation or other manipulation during construction; geometric schedules, height and direction lines, auxiliary design sketches; signs of wear and natural aging of materials; structural failures and impact of natural disasters; traces of subsequent additional modifications or conservation interventions; small epigraphical relics such as inscriptions, datings, the names of artisans or craftsmen, various graffiti etc.

The traces of working tools are among the most important ones. They allow us to reconstruct forgotten arts and techniques performed by craftsmen or artisans in the past. For tool marks examination, the original surfaces intact with no later modifications or even conservation activities are very important. The sites with authentically preserved surfaces or details should therefore be registered, documented and then rigorously protected from adverse environmental factors and, if possible, in future spared any interventions including even attempts at conservation and restoration.

Keywords: construction materials, documentation, hand tools, hand crafts, tool marks examination, traceology, use-wear analysis.
\end{abstract}

\section{Introduction}

Historical monuments fascinate a perceptive observer by the variety of styles and forms, the beauty of artistic decoration and audacity of structures built often using very simple technical means. The reasons for their protection are not just in admiration or cultural piety of our ancestors. Even for modern man they may 
be an important source of inspiration and guidance. An experienced construction historian is able to read from sites or structures in the same way that an archival scholar reads ancient manuscripts and prints. Sometimes we speak of 'the footsteps of past ages'. By that we usually mean the visible signs of aging on building materials or surfaces, or other obvious evidence of their antiquity. These qualities can be perceived without any actual theoretical knowledge or we can attempt their scientific description, classification and, preferably, positivist evaluation. In criminology the science of studying footsteps left by the perpetrator at the scene is called traceology. Analogous to that is the fact that on the surface of historical monuments there are clues that reveal what has happened in the past. Traceology is one of the methods of 'on site' surveying of historic constructions. A building historian doing traceology analysis progresses like a criminologist trying at first to distinguish and locate traces (detection phase), then to record them thoroughly and faithfully (documentation), and finally to classify and properly explain them (interpretation).

Both spheres, forensic and archaeological, may logically overlap (Fig. 1). We can easily imagine that a building construction expert's opinion on historical materials can contribute to the clarification of an actually investigated offense, or vice versa, the findings made by archaeologists can reveal some evidence about an ancient historical event with a criminal plot.

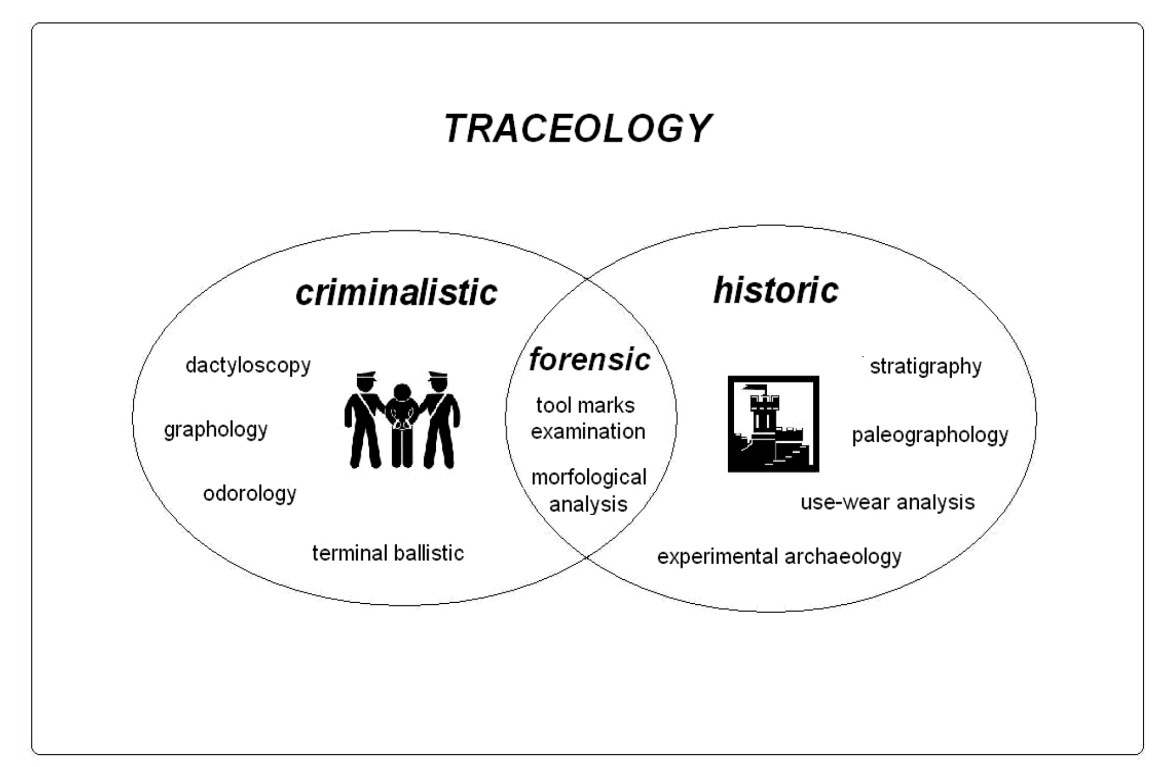

Figure 1: $\quad$ Main fields of traceology and their sub-methods. 


\section{Method}

\subsection{Classification of traces}

The location of traces must have been suitably mapped out - at the very least a hand sketch of the findings, although optimal procedure is a detailed geodetic survey of the situation, preferably processed in digital, which means a vectorized form. Traces can be also drawn out in the photographic or photogrammetric documentation. A complete picture of the layout of specific traces and their distribution in the construction (such as stone marks) can be seen by means of 3D virtual models, generated for example by laser scanning.

Similarly, the detailed recording and documentation of traces can be done through a combination of traditional methods - drawings or photographs, imprints or castings, frottage, etc. with modern methods, such as the aforementioned 3D scanning, stereophotogrammetry and many other specialized techniques.

Classification of traces according to their origin is actually a first stage of interpretation. The most commonly distinguished traces are the following:

Traces of tools used in manufacturing and processing, again in the analogy with criminology we use the term Tool Marks Examination

Imprints left by human hands during manual processing or subsequent use, appearing mainly on ceramic materials or clay surfaces

Traces of the transportation or other manipulation during construction mostly on the big timber beams and stone blocks

Geometric schedules, height and direction lines, design sketches in plaster, stone or wood, tracing floors

Signs of wear and natural aging of materials

Failures and defects, for example overloading, underestimation in the design and dimensions, impacts of natural disasters like earthquakes, floods, landslides or fires

Traces of a variety of subsequent additional modifications or conservation interventions

Decorative finishes and initial or additional small epigraphical relics like inscriptions, datings, signatures which includes vandalism (graffiti, etc.)

Already from the above summary, it is clear that in practice it is not easy to combine the findings from the site observations with the circumstances that contributed to their formation. Some of these categories can overlap or replicate (such as parts reused for repairs bear the traces of tools, transport or handling). Some of the tracks could be removed by a subsequent revision or suppressed; others are artificially created to promote the authentic impression of the monument.

It is not even that simple. An intentional patination is not only a means of masking modern repairs. In some cases it could be used even as part of the initial processing. The material used in the repair again does not necessarily come from the period of execution of this patch, it is quite common to see secondary 


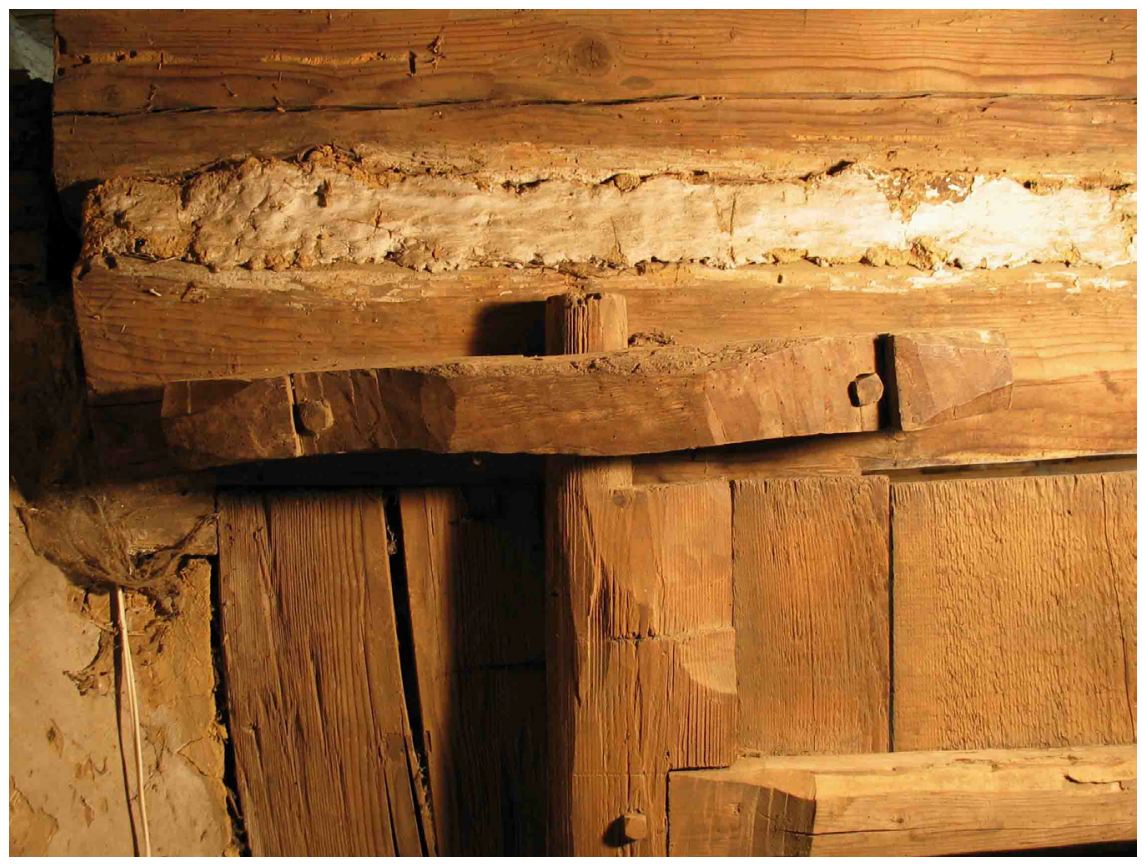

Figure 2: Wooden elements of structures reveal subtle details of manufacturing.

functional elements using older parts from dismantled buildings or even imported from elsewhere.

\subsection{Tool marks examination}

Further we would like to focus on the first mentioned group, namely the traces left by hand or mechanical tools and their interpretation. Thanks to the ability of most traditionally used construction materials to store on their surface different fingerprints, scratches or splinters, we can - according to their shape, direction, depth, and so on - deduce the size and shape of the tool or the direction of the thrust or strike. Comparison with historic illustrations gives us an opportunity to reconstruct techniques and processes no longer used and often now completely forgotten. From very ancient and even prehistoric sites, for example, where we have no iconographic material, we can use the reverse process and from the traces of wear on tools deduce the way the instruments were used or estimate what kind of material was treated. The method, based on microscopic analysis, of trying to interpret the wear traces of prehistoric tools generated during their use was significantly developed in the 1950s and 1960s by the Russian archaeologist Sergei Aristarkhovich Semenov (1898-1978). His seminal work on the subject, 'Prehistoric Technology', was first published in Moscow in 1957 and subsequently published in Britain in 1964 [11]. The traceology methods described in his book are obviously highly applicable in our case for detailed 
examination of materials and artifacts for the purpose of discovering how tools might have appeared and the operations executed with them.

Now in modern experimental archaeology there are increasing efforts not only to perform simplified reconstructions of prehistoric or early medieval buildings (using post pits to indicate the layout, fragments of the joints, etc.) but also to use copies of authentic instruments, thereby replicating the technological processes corresponding to that time.

Tool marks examination analysis in the research of cultural heritage has only appeared in recent times [8]. Specialists from the Czech Republic are now trying to extensively develop this field, with research having progressed especially in the fields of woodworking and stonemasonry, which have provided very interesting results $[3,4]$. Indeed, the author of the first book about tool marks examination in the field of criminology was Czech, a police chief sergeant named Ladislav Havlicek. He majored in criminal investigations of the picking of locks. In the 1930s, on the basis of his practical experience with the investigation of bank robberies, he theoretically defined tool marks examination as a new field of criminology calling it Mechanoscopy, and in 1940 published the handbook called 'Mechanoscopy: Traces and Signs of Craft Tools'.

\section{Construction materials}

\subsection{Timber}

Solid wood construction elements created using traditional carpentry techniques can be used as a very rich source of information about the tools which were used in different historical periods. The single blows of a broadaxe or chisel blade as well as saw teeth imprints remain visible on the surface of beams. The ability of timber to retain such subtle traces for hundreds of years is remarkable. This knowledge led us to develop a methodology focused on reading and comparing such traces in order to be able to match tools known from museum collections or old pictures with the corresponding traces. Another objective of our efforts is to identify ancient working techniques more carefully to authentically imitate them for the sake of reviving and keeping this knowledge alive as an important part of mankind's intangible cultural heritage.

In the production of long timbers for framed constructions, two main techniques of final dressing were possible in the past: hewing and sawing. In exceptional cases, traces of splitting, planing or even chiselling (carving) can also be found on beam surfaces.

By the term 'hewing' we mean shaping a piece of mature wood by means of cutting along the grain with an axe. The final products are beams made from the logs. Hewing round timbers into square profiles consists of three operations: scoring (notching), hewing and flattening. Scoring facilitates the subsequent hewing. The carpenter divides the round edge into shorter segments by making notches perpendicular to the log axis. The subsequent process of rough shaping hewing - is thereby made much easier, since the surplus mass of the timber between notches can easily be removed. The last thin layer of wood $(0.5$ to $2 \mathrm{~cm})$ is then removed with a broadaxe during flattening or planing. 


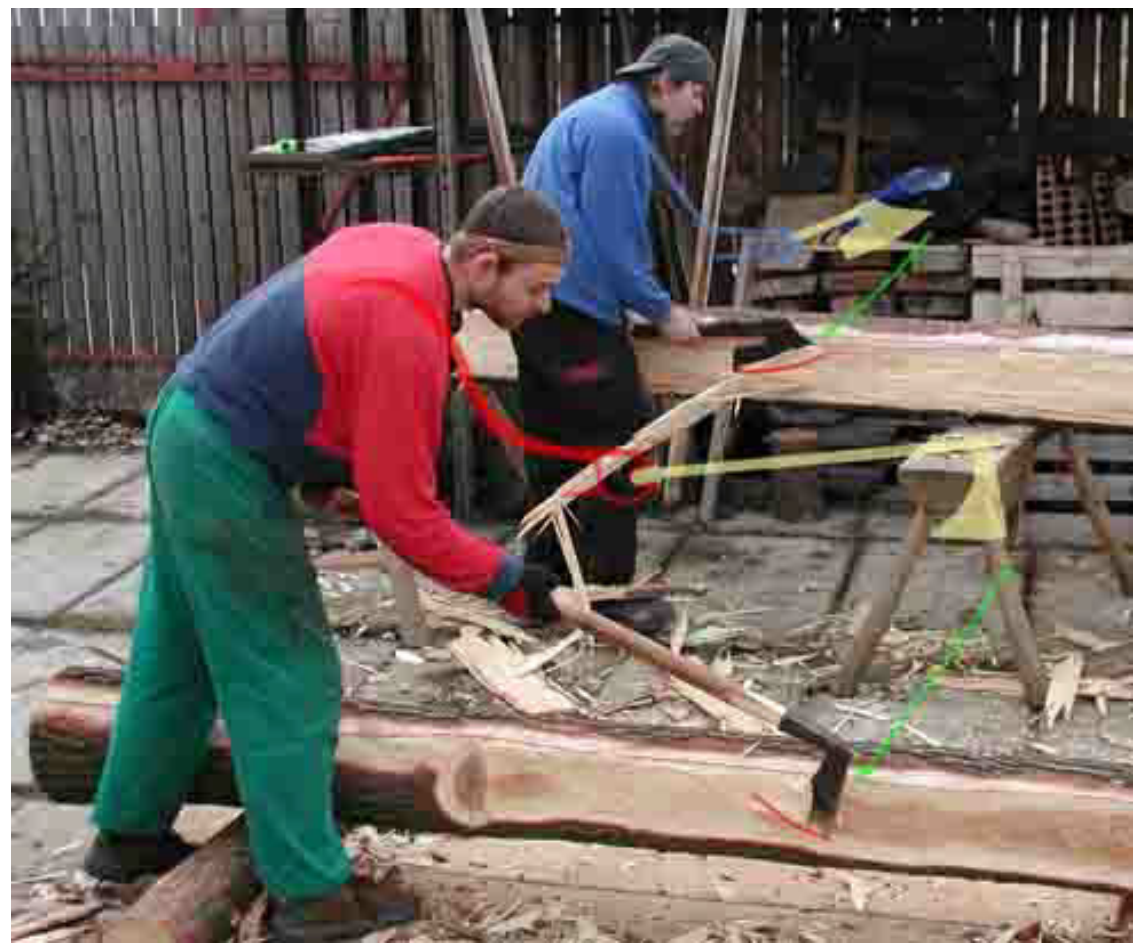

Figure 3: $\quad$ Carpenters performing low-work (front) and high-work (back).

From the appearance of splinter marks and fine scratches visible on the surface of the beam, it is possible to deduce the shape of the blade of the tool and also to identify whether a log piece was lying on the ground or placed on trestles. When performing so called 'low-work' (on the ground) carpenters used their most versatile axes with long handles and proceeded backwards while working. When doing more specialized, so-called 'high-work' (on trestles), the carpenters used broadaxes with asymmetrically shaped blades. Because the carpenter doing high-work has always progressed forward, it is even possible to determine whether he was a right-handed or left-handed craftsman. In Scandinavia and Japan the adze type of axe was widespread, which leaves quite different traces from the instruments with a lengthwise turned edge.

\subsection{Stone}

As with woodworking, each of the major steps used in processing a stone block leaves its characteristic marks, which remain legible even after the final treatment of the face. With the help of tool marks analysis we can - sometimes very well - reconstruct the working progress of a particular block. At the same time we are able to identify the types of tools, including their size, shape and even the layout of the blade or blades of the particular tool. According to the 


\section{ROUDNICE NAD LABEM - STŘEDOVĚKÝ MOST Kvádry klenebních oblouků}

obr. A - LOŽNÉ PLOCHY - plošina
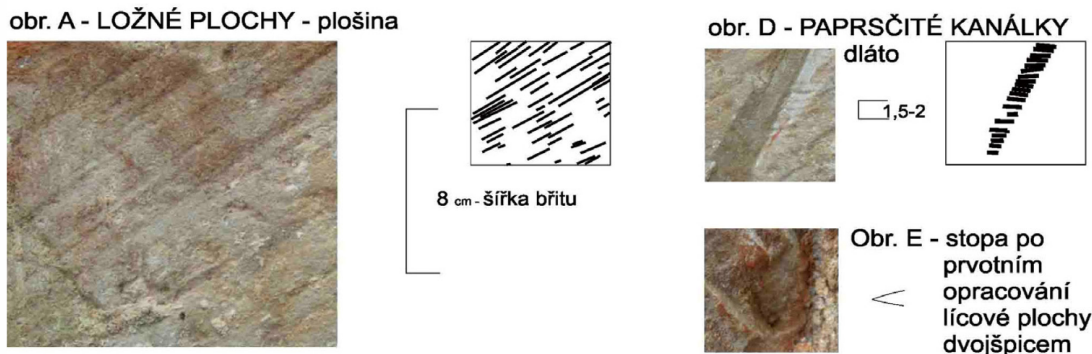

$8 \mathrm{~cm}$-šírka břitu

obr. B - STYČNÉ PLOCHY - plošina
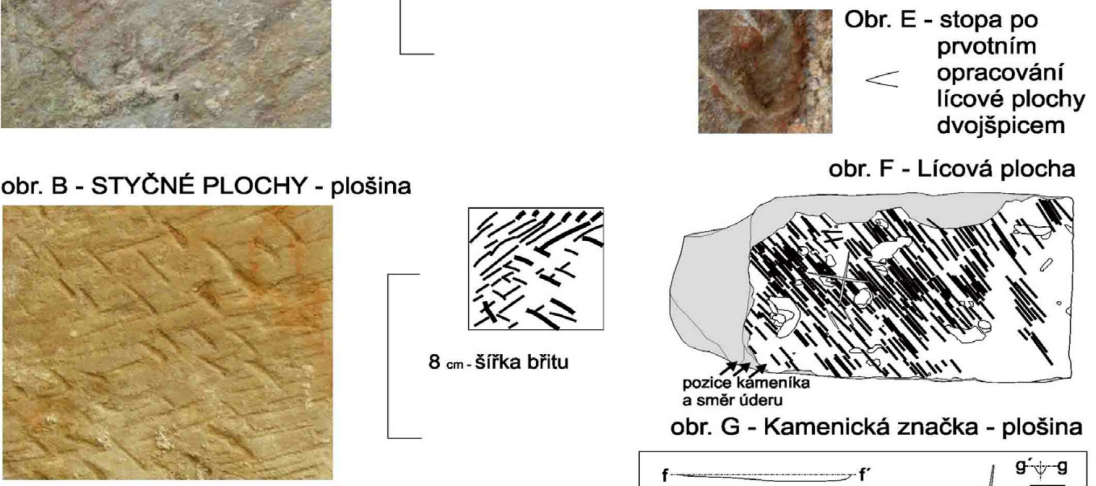

obr. F - Lícová plocha

obr. C - LíCOVÉ PLOCHY - dláto
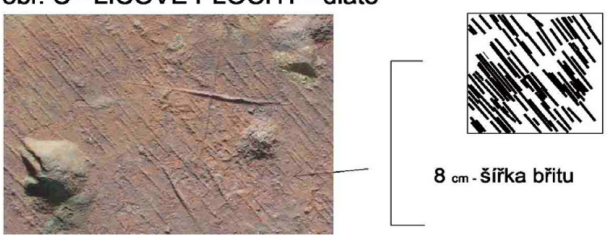

$8 \mathrm{~cm}$-šírka brìtu
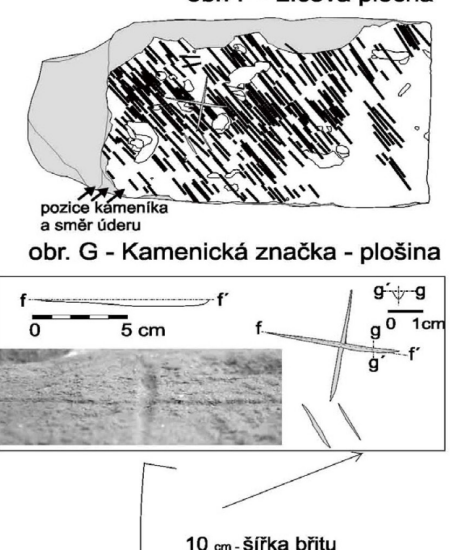

\section{ROUDNICE NAD LABEM - STŘEDOVĚKÝ MOST} Kvádry pilírư
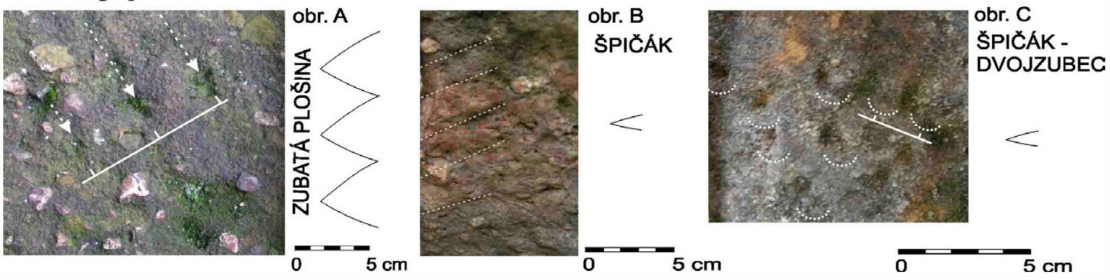

Figure 4: Example of the tool marks examination outputs: medieval stone bridge in Roudnice nad Labem in the Czech Republic (M. Panáček, M. Cihla).

final look or style of the face we can distinguish between the different ways of working and the tools used on the stone piece. If we identify and record these qualities of construction in a statistically significant sample, such as in a large cathedral, we are able to identify common characteristics recognizable as being from a single stonemason's workshop which was engaged in the construction. 
Furthermore, the information obtained can be utilized in a wider comparative research. Of course, the possibilities that this method offers always require a degree of caution and critical detachment but can produce very interesting new findings. At the same time we can additionally witness the variation of these qualities both in a certain period and in different regional styles and therefore the types of tools used in that time.

To describe the course of action and the subsequent division of processing according to the type of instrument we can look at the production of a block from soft sedimentary rocks such as sandstone, limestone or marlite. When harder rock types, such as granite and granodiorite, were used they required slightly different instruments and traces from working on them are less pronounced and harder to read due to the hardness of the rock.

In order to remove anomalies from the original large rough block, it was first necessary for a mason to use a pick hammer to cut the block into a regular shape. After that the process of creating a smooth, flat trail along one of the longest edges of the stone block began. To do this a stonemason would make careful and regular strikes with a mallet onto his chisel. In the same plane, which he checked with a mason's ruler, he then cut out the edge of the trail on one of the shorter sides of the stone block. He then cut the two remaining sides, thus creating a circumferential path on all four sides of the plane of one set of block surfaces. The surplus mass above the plane he then roughly removed with a mallet and a canine or pick hammer. Using the same method, he then shaped the other planes of the block using an angle ruler to correctly determine the angles of the block. To complete the basic working of the inner surfaces on every side of the stone block a pick hammer was usually used. The final texture of the visible surfaces of the block was achieved with one of a variety of tools which provided for different degrees of roughness or smoothness. These same or similar tools were used for the application of decorative patterns and for more elaborate stonework elements, some of which were then even more polished and glazed. Traces from the same tools can be found in sculptures, tombs and gravestones.

\subsection{Plaster}

Hand-applied plaster layers are never perfectly straight so, depending on the nature of the inequalities on the surface, we can estimate reasonably accurately the method of coating, smearing, or smoothing used. In the past, for finishing the plaster, artisans used a diverse array of instruments - wooden or metal trowels and floats as well as tools partly made of leather or fur, or different types of brushes. Another technique we can recognize is so-called tightening of the surfaces which was done in order to push excess water along with fine particles of filler to the surface layer. To define the shape of stucco cornices and other linear elements, sliding templates were used which were carved with the desired profile. 


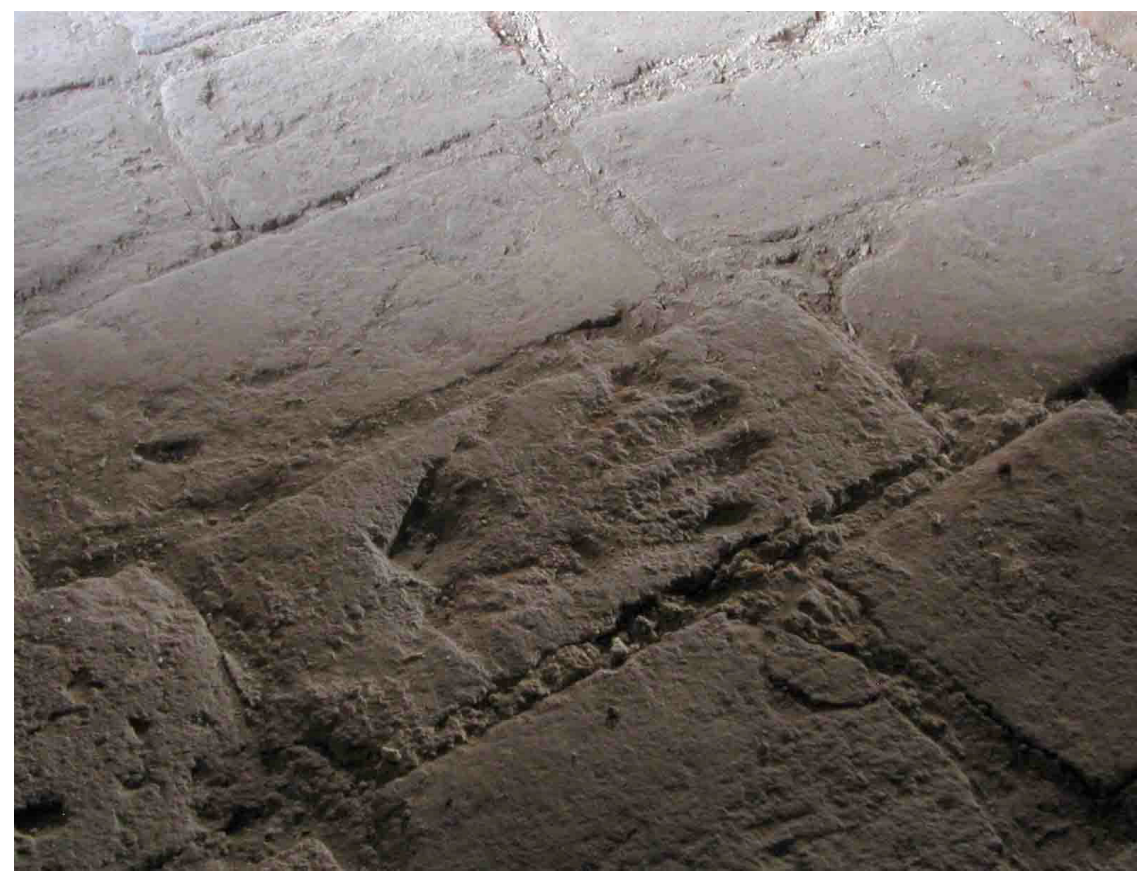

Figure 5: Handprint on the surface of burned brick tile - a man made fossil.

\subsection{Ceramic bricks, floor and roof-tiles}

Usually small prefabricated elements, shaped before firing in the kiln either manually or using forms. On old roof-tiles we can often find grooves created by fingertips to better channel water away from the edges. Frequently there are also prints of wooden moulds or factory stamps distinctive to individual workshops.

\section{Conclusion}

Detailed traceological studies of historical monuments bring fresh knowledge for scientific research into forgotten craft practices. The rapid progress of digitalisation and the publication of historical iconographic documents, sorted and labelled by keywords, helps in the development of this method. In tool marks examination, of essential and irreplaceable importance is the finding of a situation with an intact original surface which has never been touched by the hand of a restorer. In interiors such places are located where vaults or lower ceilings were inserted later into the previously higher rooms. On the facades such original surfaces are found mainly in places covered by later raised roofs or extensions of adjacent wings.

The carved wooden beams and stonework shaped elements often reveal that they have been reused for reasons of economy when repairing or rebuilding and at that time were often shortened, rotated or otherwise adjusted. Investigating 
these situations is another option in trying to get to material with an authentic surface, often much older than the context in which they now appear to have been used. Examples of such discoveries are decorated beams and painted wooden tiles or slabs which have subsequently been used as floors or as lightweight wooden partitions within attics.

The sites with authentically preserved surfaces or details should therefore be registered, documented and then rigorously protected from adverse environmental factors and, if possible, in future spared any interventions including even attempts at conservation and restoration.

\section{Acknowledgement}

This paper was created with a financial support from the grant project DF12P01OVV020 "A comprehensive methodology for the selection and processing of a stone intended for replacements and repairs of the ashlar masonry of historic buildings", NAKI program, provided by the Ministry of Culture of the Czech Republic and institutional support RVO 68378297.

\section{References}

[1] Binding, Günther, Baubetrieb im Mittelalter. Darmstadt 1993.

[2] Binding, Günther, Der mittelalterliche Baubetrieb in zeitgenössischen Abbildungen. Darmstadt 2001.

[3] Bláha, Jiří, Janák, Karel and Růžička, Petr, Les traces du travail de bois/Traces of woodworking tools. In: Hoffsummer, Patrick - Eeckhout, Jerôme (eds.): Matériaux de l'architecture et Toits de l'Europe/Materials of Architectural Heritage and Historical Roofs of Europe, Les Dossiers de L'IPW, 6, Namur, pp. 119-139, 2008.

[4] Bláha, Jiř́: Les traces technologiques de la fabrication et du levage des charpentes/Traces of construction techniques and processes. In: Hoffsummer, Patrick and Eeckhout, Jerôme (eds.): Matériaux de l'architecture et Toits de l'Europe/Materials of Architectural Heritage and Historical Roofs of Europe, Les Dossiers de L'IPW, 6, Namur, pp. 140150, 2008.

[5] Blair, John and Ramsay, Nigel: English medieval industries: craftsmen, techniques, products, The Hambledon Press, London and Rio Grande, 446 p, 1991.

[6] Doperé, Frans, Les techniques de taille sur le grès calcareux Une nouvelle méthode pour déterminer la chronologie et étudier l'evolution des chantiers dans l'est du Brabant pendant la première moitié du XVe siècle, In: Lodewijcks, Marc (ed.): Archaeological and Historical Aspects of WestEuropean Societes, Acta Archaeologica Lovaniensia Monographiae No. 8, Leuven University Press, pp. 415-440, 1996.

[7] Drdácký Miloš, Mlázovský, Vit and Růžička, Petr, Historic Carpentry in Europe: Discoveries and Potential. In: ATP Bulletin: The Journal of Preservation Technology 2-3, pp. 33-41, 2004. 
[8] Hewett, Cecil Alec: Tool-marks on Surviving Works from the Saxon, Norman and Later Medieval Period. In: McGrail, Sean (ed.): Woodworking Technique Before A. D. 1500, Oxford, pp. 339-348, 1982.

[9] Holton, Alexander: The working space of the medieval master mason: the tracing houses of York Minster and Wells Cathedral. In: Proceedings of the Second International Congress on Construction History, Volume II, pp. 1579-1597, 2006.

[10] Reveyron, Nicolas: Marques Lapidaires: The State of the Question. In: Gesta Vol. 42, No. 2, pp. 161-170, 2003.

[11] Semenov, Sergei Aristarkhovich, Prehistoric Technology: An Experimental Study of the Oldest Tools and Artefacts from Traces of Manufacture and Wear. Trans. M. W. Thompson. London: Cory, Adams and c Mackay/New York: Barnes and Noble. [Reprinted, Adams 8c Dart, Bath, UK 1973; Barnes and Noble, Totowa, NJ 1985.] 